\title{
HUBUNGAN BEBAN KERJA DAN KELELAHAN KERJA DENGAN TURNOVER INTENTION PADA PEKERJA OUTSOURCING PT X TAHUN 2020
}

\author{
Putu Intan Tillama, I Md. Ady Wirawan* \\ Program Studi Sarjana Kesehatan Masyarakat Fakultas Kedokteran Universitas Udayana \\ *Email:ady.wirawan@unud.ac.id
}

\begin{abstract}
ABSTRAK
Pekerjaan di bandar udara didominasi oleh sektor penyedia jasa, seperti ground handling yang mengharuskan pekerjanya berhadapan langsung dengan konsumen, serta dihadapkan dengan intensitas kerja tinggi akibat padatnya jadwal penerbangan. Sehingga, dapat memengaruhi beban kerja yang diterima serta rentan mengalami kelelahan, dan dapat menyebabkan adanya turnover intention pada pekerja. Selain itu, angka turnover pekerja outsourcing di PT X pada tahun 2019 mencapai 197 orang dengan persentase 28\%. Apabila turnover tahunan dalam suatu perusahaan mencapai angka 10\%, maka turnover pada perusahaan tersebut dapat dikategorikan tinggi. Tujuan penelitian ini adalah untuk mengetahui hubungan antara beban kerja dan kelelahan kerja dengan turnover intention pada pekerja outsourcing di bandar udara. Penelitian analitik dengan pendekatan kuantitatif menggunakan rancangan cross-sectional. Responden penelitian berjumlah 137 orang yang dipilih dengan menggunakan metode stratified random sampling. Beban kerja fisik $(p=0,2702)$ dan beban kerja mental $(p=0,5181)$ tidak memiliki hubungan dengan turnover intention. Sedangkan, kelelahan kerja memiliki hubungan ringan positif dengan turnover intention $(\mathrm{p}=0,0056)$.
\end{abstract}

Kata Kunci: ground handling, beban kerja, kelelahan kerja, turnover intention, pekerja outsourcing

\begin{abstract}
Occupation in airports are dominated by service provider sectors, such as ground handling which requires the workers to deal with the consumers directly, and are faced with high work intensity due to the tight flight schedules. Thus, it can affect the workload that received and prone to fatigue, and can cause turnover intention among workers. The turnover rate of outsourced workers at PT X in 2019 is 28\%, with 197 people in total. If the annual turnover rate in a company reaches $10 \%$, then the turnover in that company can be categorized as high. The aim of this study is to determine the correlation between workload and work fatigue with turnover intention in outsourced workers at airports. This analytical research with a quantitative approach using a cross-sectional design. The number of respondents are 137 people who were selected using the stratified random sampling method. Physical workload $(\mathrm{p}=0.2702)$ and mental workload $(\mathrm{p}=0.5181)$ have no correlation with turnover intention. Meanwhile, work fatigue has a positive mild correlation with turnover intention $(\mathrm{p}=0.0056)$.
\end{abstract}

Keywords: ground handling, workload, work fatigue, turnover intention, outsourced workers

\section{PENDAHULUAN}

Industri penerbangan senantiasa berkembang dengan pesat sebagai salah satu transportasi primadona masyarakat. Meningkatnya demand dari masyarakat menyebabkan semakin maraknya jasa angkutan udara (Mora, 2012). Perkembangan industri tersebut seiring dengan meningkatnya kebutuhan jasa pelayanan penerbangan, salah satunya adalah jasa ground handling. Ground handling mencakup pelayanan terhadap penumpang, bagasi, kargo dan pos yang diangkut pesawat udara, serta penyediaan peralatan untuk membantu pergerakan pesawat di darat selama berada di bandar udara, baik pada fase kedatangan maupun keberangkatan.

Setiap perusahaan tentu berusaha untuk mempertahankan jumlah sumber daya manusianya, demi kelancaran proses pelayanan jasa maupun produksi. Namun, perusahaan kerap dihadapi dengan berbagai permasalahan terkait sumber daya manusianya. Salah satu kendala yang 
sering terjadi pada perusahaan adalah adanya keinginan pindah kerja (turnover intention) yang berujung pada keputusan pekerja untuk meninggalkan pekerjaannya. Turnover intention atau niat pindah kerja karyawan yang tinggi akan merugikan perusahaan baik finansial maupun non finansial. Menurut Ghosh et al (2013), turnover berdasarkan keputusan seorang pekerja yang dilakukan baik dengan kemauan sendiri maupun bukan kemauan sendiri. Mobley (2011) berpendapat bahwa faktor yang memengaruhi turnover intention meliputi karakteristik individu, lingkungan kerja, kepuasan kerja, dan komitmen organisasi. Selain faktor-faktor di atas, penulis menggunakan variabel beban kerja dan kelelahan kerja sebagai salah satu penyebab turnover intention.

Beban kerja yang diemban setiap pekerja merupakan salah satu faktor yang memengaruhi turnover intention. Girdano \& Everly (1980), mengatakan bahwa beban kerja adalah keadaan ketika pekerja dihadapkan pada suatu tugas atau pekerjaan yang harus diselesaikan pada waktu tertentu. Menurut Manuaba (2000) beban dapat berupa fisik dan mental. Beban fisik dapat dilihat dari seberapa banyak karyawan menggunakan kekuatan fisiknya. Sedangkan beban kerja mental dapat dilihat dari seberapa besar akitivitas mental yang dibutuhkan untuk berkonsentrasi, mendeteksi permasalahan, dan membuat keputusan.

Berdasarkan penelitian terdahulu, Suwanto et al (2014) menyatakan bahwa ada hubungan antara beban kerja dengan minat pindah kerja pada perawat TKS. Irvianti \& Verina (2015) melakukan penelitian mengungkapkan bahwa beban kerja memiliki pengaruh yang sangat kuat dan searah (positif) terhadap turnover intention.

Selain beban kerja, kelelahan kerja juga merupakan penyebab turnover intention. Kelelahan kerja merupakan kondisi yang menunjukkan keadaan tubuh secara fisik dan mental yang mengakibatkan adanya penurunan daya kerja serta ketahanan tubuh (Budiono, 2008). Menurut Suma'mur (2009) kelelahan kerja merupakan suatu mekanisme perlindungan agar tubuh terhindar dari kerusakan lebih lanjut, sehingga terjadilah pemulihan setelah istirahat.

Ardiyanti (2019) melakukan penelitian bahwa kelelahan kerja memiliki pengaruh yang signifikan terhadap turnover intention. Selain itu, berdasarkan hasil penelitian yang dilakukan oleh Rizal \& Badaruddin (2017), menunjukan bahwa adanya pengaruh positif dan signifikan antara kelelahan kerja terhadap turnover intention pegawai.

Berdasarkan studi pendahuluan yang dilakukan penulis di PT X, pekerja outsourcing yang mengalami turnover pada tahun 2019 mencapai 197 orang. Setiap bulannya pada tahun 2019 terdapat pekerja outsourcing yang mengalami turnover dengan jumlah tertinggi pada bulan April sebanyak 25 orang dan jumlah terendah pada bulan Maret sebanyak lima orang. Menurut Roseman (1981), apabila turnover tahunan dalam suatu perusahaan mencapai angka 10\%, maka turnover pada perusahaan tersebut dapat dikategorikan tinggi. PT $X$ yang mempekerjakan tenaga outsourcing hingga mencapai 700 orang lebih, menujukkan bahwa angka turnover mencapai 197 orang dengan persentase 
$28 \%$ dalam satu tahun dapat dikategorikan tinggi.

Berdasarkan penelitian-penelitian yang telah dilakukan sebelumnya, belum terdapat penelitian terkait hubungan beban kerja dan kelelahan kerja dengan turnover intention yang dilakukan pada pekerja di bandar udara maupun pekerja outsourcing. Pekerjaan di bandar udara didominasi oleh sektor penyedia jasa, seperti ground handling yang mengharuskan pekerjanya berhadapan langsung dengan konsumen, serta dihadapkan dengan intensitas kerja tinggi akibat padatnya jadwal penerbangan. Sehingga, dapat memengaruhi beban kerja yang diterima serta rentan mengalami kelelahan, dan dapat menyebabkan adanya turnover intention pada pekerja. Alasan diperkuat dengan tingginya jumlah pekerja yang mengalami turnover pada perusahaan dalam kurun waktu setahun terakhir. Maka dari itu, penulis tertarik melakukan penelitian untuk mengetahui adanya hubungan antara beban kerja dan kelelahan kerja dengan turnover intention pada pekerja outsourcing PT X.

\section{METODE PENELITIAN}

Desain penelitian yang digunakan adalah cross-sectional dengan metode analitik dan pendekatan kuantitatif. Penelitian dilakukan untuk mencari hubungan antara variabel bebas dengan variabel tergantung dan dilakukan analisis terhadap data yang diperoleh. Populasi target dalam penelitian ini adalah pekerja outsourcing di bandar udara. Sedangkan, populasi terjangkau dalam penelitian ini adalah pekerja outsourcing di PT X yang berjumlah 465 orang. Perhitungan besar sampel menggunakan rumus uji hipotesis 2 proporsi dengan jumlah sampel minimun 137 orang. Teknik sampling yang digunakan dalam penelitian ini adalah stratified random sampling untuk membagi jumlah sampel pada kedua unit pekerjaan, yaitu pada unit airside dan landside. Selanjutnya responden dipilih secara acak pada masing-masing unit kerja.

Pengumpulan data menggunakan kuesioner dilakukan secara online menggunakan google form. Hal ini dilakukan karena mengikuti arahan physical distancing dalam situasi pandemi. Pengambilan data diawali dengan penjelasan tujuan penelitian dan informed consent. Apabila responden bersedia dilanjutkan dengan pengisian kuesioner online. Kuesioner yang digunakan adalah kuesioner Physical Load Index (PLI), kuesioner National Aeronautics \& Space Administration Task Load Index (NASATLX), Kuesioner Alat Ukur Perasaan Kelelahan Kerja (KAUPK2), dan kuesioner untuk mengukur turnover intention yang diambil dari penelitian Dwiningtyas (2015) berdasarkan indikator pengukuran turnover intention menurut Mobley et al (1978).

Analisis data yang dilakukan adalah analisis deskriptif dan analisis bivariabel untuk menggambarkan hubungan antara beban kerja dan kelelahan kerja dengan turnover intention. Uji statistik yang digunakan adalah uji statistik non parametrik, yaitu korelasi spearman. Uji korelasi spearman digunakan karena data dalam skala ordinal. 
HASIL

Tabel 1. Karakteristik Responden

\begin{tabular}{|c|c|c|}
\hline $\begin{array}{c}\text { Karakteristik } \\
\text { Responden }\end{array}$ & $\begin{array}{l}\text { Frekuensi } \\
\text { (n) }\end{array}$ & $\begin{array}{c}\text { Proporsi } \\
(\%)\end{array}$ \\
\hline \multicolumn{3}{|l|}{ Usia } \\
\hline$\leq 25$ Tahun & 96 & 70,07 \\
\hline$>25$ Tahun & 41 & 29,93 \\
\hline \multicolumn{3}{|l|}{ Masa Kerja } \\
\hline$\leq 3$ Tahun & 63 & 45,99 \\
\hline$>3$ Tahun & 74 & 54,01 \\
\hline \multicolumn{3}{|l|}{ Pendidikan } \\
\hline SMA/SMK & 76 & 55,47 \\
\hline Diploma & 47 & 34,31 \\
\hline Perguruan Tinggi & 14 & 10,22 \\
\hline
\end{tabular}

Berdasarkan Tabel 1, usia responden pada penelitian ini dibedakan menjadi dua kategori, yaitu $\leq 25$ tahun dan $>25$ tahun. Responden dengan usia $\leq 25$ tahun (70,07\%) lebih banyak daripada responden berusia $>25$ tahun $(29,93 \%)$. Usia responden termuda pada penelitian ini adalah 18 tahun, sedangkan usia tertua adalah 42 tahun dengan rata-rata (SD) umur adalah 24,33 (SD=4,71) tahun. Masa kerja responden juga dibedakan menjadi dua kategori, yaitu $\leq 3$ tahun dan $>3$ tahun, dengan rata-rata (SD) masa kerja adalah 4,26 ( $\mathrm{SD}=3,25)$ tahun. Sebanyak 45,99\% responden telah $\leq 3$ tahun, dan 54,01\% responden telah bekerja selama lebih dari tiga tahun. Masa kerja terlama responden adalah lima belas tahun dan tersingkat kurang dari satu tahun. Dilihat dari tingkat pendidikan, 55,47\% responden merupakan lulusan SMA/SMK, 34,31\% responden merupakan diploma, dan 10,22\% responden lulusan perguruan tinggi.

Beban kerja fisik diukur menggunakan kuesioner Physical Load Index (PLI) yang diperkenalkan oleh
Hollmann et al (1999). Berdasarkan Tabel 2, dari keseluruhan responden sebanyak 8,03\% mengalami beban kerja fisik berat, $53,28 \%$ mengalami beban kerja fisik sedang, dan 38,69\% mengalami beban kerja fisik relatif ringan.

Tabel 2. Gambaran Beban Kerja Fisik

\begin{tabular}{lcc}
\multicolumn{3}{c}{ Responden } \\
\hline Kategori & $\begin{array}{c}\text { Frekuensi } \\
\text { (n) }\end{array}$ & $\begin{array}{c}\text { Proporsi } \\
\mathbf{( \% )}\end{array}$ \\
\hline Berat & 11 & 8,03 \\
Sedang & 73 & 53,28 \\
Relatif Ringan & 53 & 38,69 \\
\hline
\end{tabular}

Tabel 3. Gambaran Beban Kerja Fisik

Responden Berdasarkan Unit Kerja

\begin{tabular}{lcc}
\hline \multirow{2}{*}{ Kategori } & \multicolumn{2}{c}{ Unit } \\
\cline { 2 - 3 } & Landside & Airside \\
& $\mathbf{n}(\mathbf{\%})$ & $\mathbf{n}(\mathbf{\%})$ \\
\hline Berat & $10(9,52)$ & $1(3,13)$ \\
Sedang & $61(58,1)$ & $12(37,5)$ \\
Relatif Ringan & $34(32,38)$ & $19(59,38)$ \\
\hline
\end{tabular}

Berdasarkan Tabel 3, pada unit landside responden dengan kategori beban kerja fisik sedang merupakan yang terbanyak, yaitu 58,1\%. Sebanyak 9,52\% mengalami beban kerja fisik berat dan $32,38 \%$ mengalami beban kerja fisik relatif ringan. Pada unit airside responden dengan kategori beban kerja fisik relatif ringan merupakan yang terbanyak, yaitu 59,38\%. Sebanyak 3,13\% mengalami beban kerja fisik berat dan 37,5\% mengalami beban kerja fisik sedang.

Berdasarkan Gambar 1, pada bagian sikap tubuh tanggapan responden terbanyak adalah tidak pernah, yaitu 25,69\%. Pada bagian sikap lengan tanggapan responden terbanyak adalah 
jarang, yaitu 30,17\%. Tanggapan terbanyak pada sikap kaki adalah sangat sering, yaitu $25,84 \%$, diikuti dengan sering sebanyak $25,4 \%$. Sedangkan, tanggapan terbanyak responden pada bagian beban yang diangkat pada sikap tubuh tegak dan beban yang diangkat pada sikap tubuh condong adalah kadang-kadang, yaitu $29,93 \%$ dan $29,68 \%$.

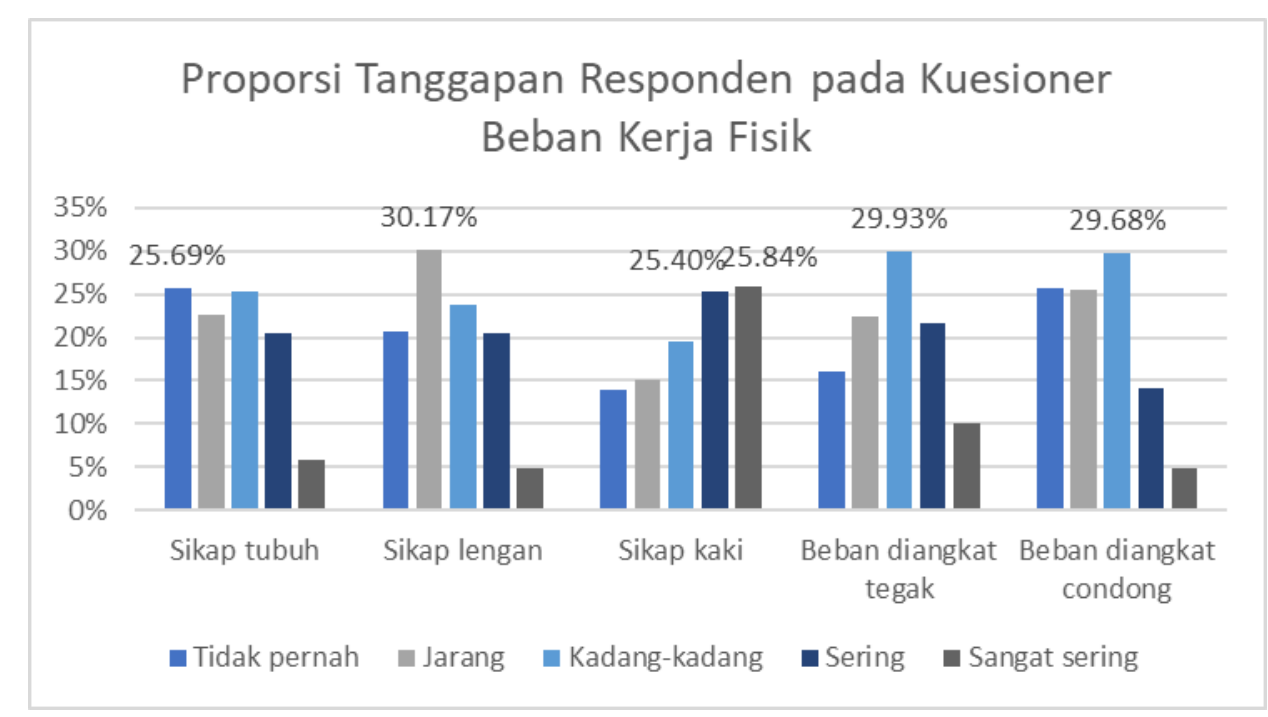

Gambar 1. Proporsi Tanggapan Responden pada Kuesioner Beban Kerja Fisik

Pengukuran beban kerja mental pada penelitian ini menggunakan kuesioner NASA-TLX yang dikembangkan oleh Hart \& Staveland (1988) dengan membagi beban kerja menjadi 6 skala. Pertanyaan dibagi menjadi 2 bagian, yaitu pembobotan dan pemberian rating.

Tabel 4. Gambaran Beban Kerja Mental

\begin{tabular}{lcc}
\multicolumn{3}{c}{ Responden } \\
\hline Kategori & $\begin{array}{c}\text { Frekuensi } \\
\text { (n) }\end{array}$ & $\begin{array}{c}\text { Proporsi } \\
\mathbf{( \% )}\end{array}$ \\
\hline Sangat Tinggi & 74 & 54,01 \\
Tinggi & 43 & 31,39 \\
Agak Tinggi & 10 & 7,3 \\
Sedang & 9 & 6,57 \\
Rendah & 1 & 0,73 \\
\hline
\end{tabular}

Berdasarkan Tabel 4, responden yang mengalami beban kerja mental sangat tinggi merupakan yang terbanyak, yaitu $54,01 \%$. Diikuti dengan responden yang mengalami beban kerja mental tinggi sebanyak 31,39\%.

Tabel 5. Gambaran Beban Kerja Mental

\section{Responden Berdasarkan Unit Kerja}

\begin{tabular}{lcc}
\hline \multirow{2}{*}{ Kategori } & \multicolumn{2}{c}{ Unit } \\
\cline { 2 - 3 } & $\begin{array}{c}\text { Landside } \\
\mathbf{n ~ ( \% )}\end{array}$ & $\begin{array}{c}\text { Airside } \\
\text { n (\%) }\end{array}$ \\
\hline Sangat Tinggi & $61(58,1)$ & $13(40,63)$ \\
Tinggi & $33(31,43)$ & $10(31,25)$ \\
Agak Tinggi & $6(5,71)$ & $4(12,5)$ \\
Sedang & $4(3,81)$ & $5(15,63)$ \\
Rendah & $1(0,95)$ & $0(0)$ \\
\hline
\end{tabular}

Berdasarkan Tabel 5, responden pada unit landside yang mengalami beban kerja mental sangat tinggi merupakan yang terbanyak, yaitu 58,1\%. Diikuti dengan responden yang mengalami beban kerja mental tinggi sebanyak 31,43\%. Sedangkan, responden pada unit airside yang mengalami beban kerja mental sangat tinggi merupakan yang terbanyak, yaitu 
40,63\%. Diikuti dengan responden yang sebanyak $31,25 \%$. mengalami beban kerja mental tinggi

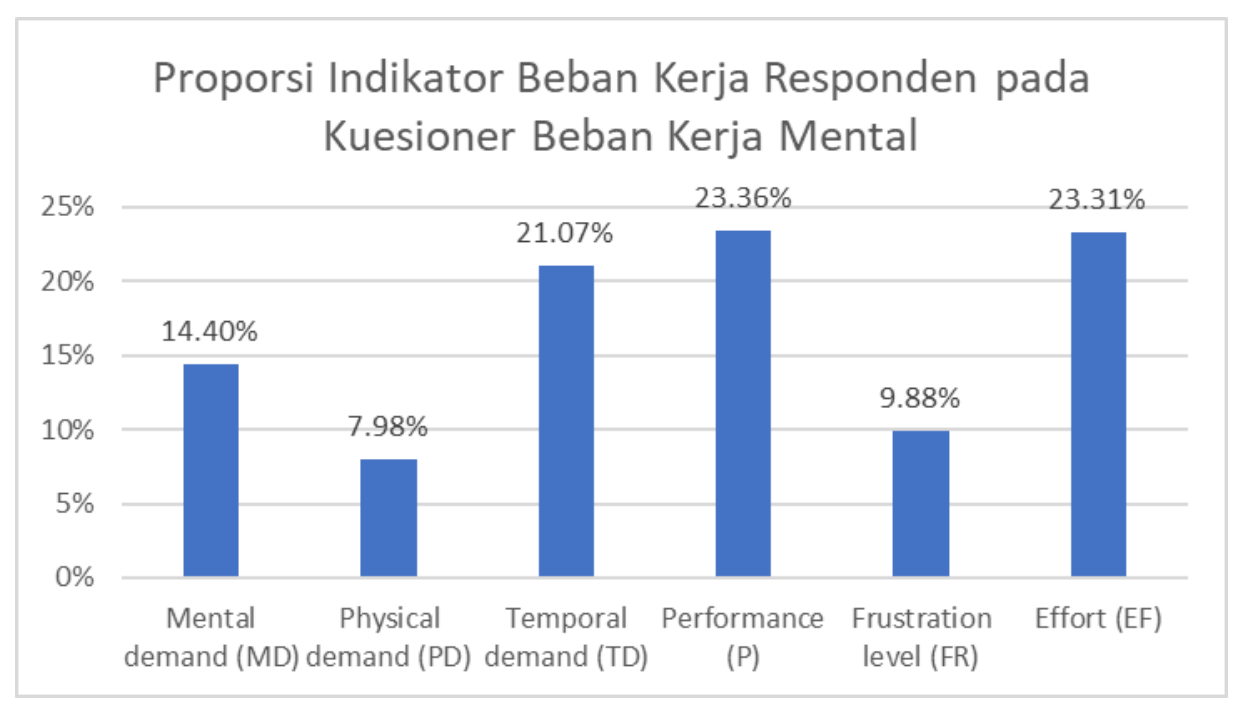

Gambar 2. Proporsi Indikator Beban Kerja Responden pada Kuesioner Beban Kerja Mental

Berdasarkan Gambar 2, indikator dengan jumlah terbanyak yang dipilih sebagai yang dirasakan lebih dominan oleh responden adalah performance $(\mathrm{P})$, yaitu $23,36 \%$, diikuti dengan effort (EF) sebanyak 23,31\%. Sedangkan, indikator dengan jumlah paling sedikit adalah physical demand (PD), yaitu 7,98\%.

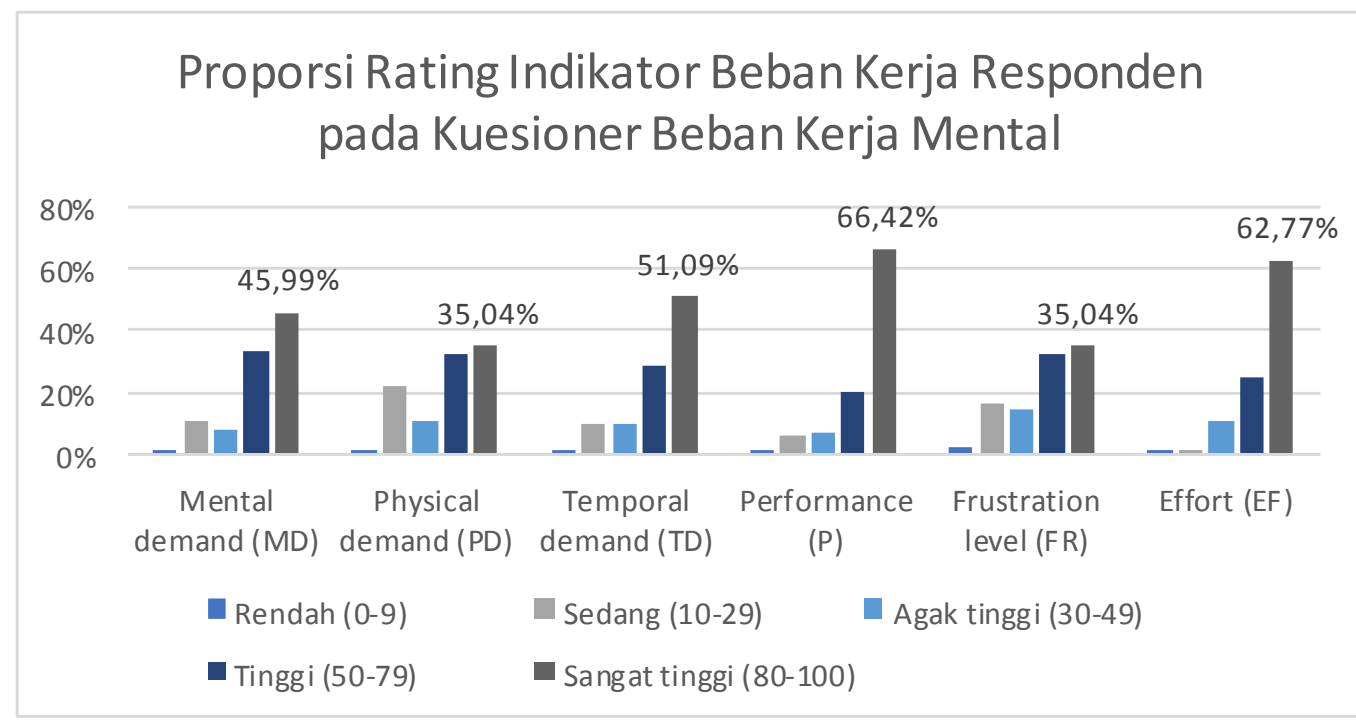

Gambar 3. Proporsi Rating Indikator Beban Kerja Responden pada Kuesioner Beban Kerja Mental

Berdasarkan Gambar 3, rating pada seluruh indikator beban kerja mental yang paling banyak dipilih responden adalah sangat tinggi (80-100).
Kelelahan kerja pada responden diukur menggunakan Kuesioner Alat Ukur Perasaan Kelelahan Kerja yang didesain oleh Setyawati (2010) khusus untuk pekerja 
di Indonesia. Berdasarkan Tabel 6, sebanyak 9,49\% responden dalam keadaan sangat lelah, 85,4\% responden dalam keadaan lelah, dan 5,11\% responden tidak mengalami kelelahan.

Tabel 6. Gambaran Kelelahan Kerja Responden

\begin{tabular}{lcc}
\hline \multicolumn{1}{c}{ Kategori } & $\begin{array}{c}\text { Frekuensi } \\
\text { (n) }\end{array}$ & $\begin{array}{c}\text { Proporsi } \\
(\mathbf{\%})\end{array}$ \\
\hline Sangat Lelah & 13 & 9,49 \\
Lelah & 117 & 85,4 \\
Tidak Lelah & 7 & 5,11 \\
\hline
\end{tabular}

Berdasarkan Tabel 7, responden pada unit landside yang lelah merupakan yang terbanyak, yaitu $84,76 \%$. Diikuti dengan responden sangat lelah sebanyak 9,52\% dan 5,71\% responden dalam keadaan tidak lelah. Responden pada unit airside yang lelah merupakan yang terbanyak, yaitu $87,5 \%$. Diikuti dengan responden sangat lelah sebanyak 9,38\% dan 3,13\% responden dalam keadaan tidak lelah.

Tabel 7. Gambaran Kelelahan Kerja

Responden Berdasarkan Unit Kerja

\begin{tabular}{lcc}
\hline \multirow{2}{*}{ Kategori } & \multicolumn{2}{c}{ Unit } \\
\cline { 2 - 3 } & $\begin{array}{c}\text { Landside } \\
\mathbf{n}(\mathbf{\%})\end{array}$ & $\begin{array}{c}\text { Airside } \\
\mathbf{n ~ ( \% )}\end{array}$ \\
\hline Sangat Lelah & $10(9,52)$ & $3(9,38)$ \\
Lelah & $89(84,76)$ & $28(87,5)$ \\
Tidak Lelah & $6(5,71)$ & $1(3,13)$ \\
\hline
\end{tabular}

Berdasarkan Gambar 4, pada aspek pelemahan aktivitas dan aspek gejala fisik tanggapan responden terbanyak adalah ya, jarang sebanyak 55,6\% dan 48,05\%. Sedangkan, tanggapan responden terbanyak pada aspek pelemahan motivasi adalah tidak pernah, yaitu 62,04\%.

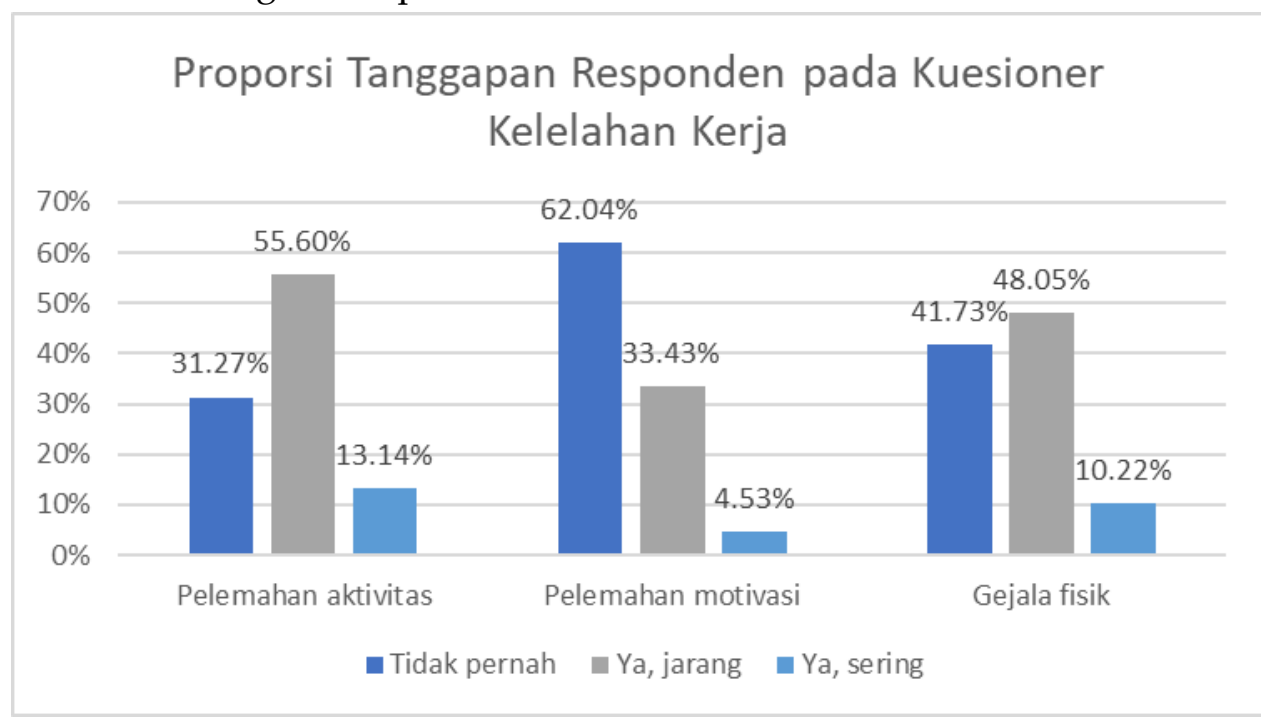

Gambar 4. Proporsi Tanggapan Responden pada Kuesioner Kelelahan Kerja

Turnover intention responden diukur menggunakan kuesioner yang diambil dari penelitian Dwiningtyas (2015) yang telah teruji validitas dan reabilitasnya. Kesembilan pertanyaan dalam kuesioner berdasarkan pada indikator pengukuran turnover intention menurut Mobley et al (1978).

Berdasarkan Tabel 8, responden dengan turnover intention sedang merupakan yang terbanyak, yaitu $42,34 \%$. Diikuti jumlah responden dengan turnover 
intention tinggi sebanyak 30,66\%. Jumlah responden dengan turnover intention sangat rendah merupakan yang paling sedikit, yaitu hanya 5,11\%.

Tabel 8. Gambaran Turnover Intention Responden

\begin{tabular}{lcc}
\hline \multicolumn{1}{c}{ Kategori } & $\begin{array}{c}\text { Frekuensi } \\
\text { (n) }\end{array}$ & $\begin{array}{c}\text { Proporsi } \\
\text { (\%) }\end{array}$ \\
\hline Sangat Tinggi & 12 & 8,76 \\
Tinggi & 42 & 30,66 \\
Sedang & 58 & 42,34 \\
Rendah & 18 & 13,14 \\
Sangat Rendah & 7 & 5,11 \\
\hline
\end{tabular}

Berdasarkan Tabel 9, responden pada unit landside dengan turnover intention sedang merupakan yang terbanyak, yaitu $42,86 \%$. Diikuti dengan turnover intention tinggi sebanyak 30,48\%. Jumlah responden dengan turnover intention sangat rendah merupakan yang paling sedikit, yaitu hanya $4,76 \%$. Responden pada unit airside dengan turnover intention sedang merupakan yang terbanyak, yaitu 40,63\%. Diikuti dengan turnover intention tinggi sebanyak 31,25\%. Jumlah responden dengan turnover intention sangat tinggi merupakan yang paling sedikit, yaitu hanya 3,13\%.

Tabel 9. Gambaran Turnover Intention

Responden Berdasarkan Unit Kerja

\begin{tabular}{lcc}
\hline \multirow{2}{*}{ Kategori } & \multicolumn{2}{c}{ Unit } \\
\cline { 2 - 3 } & Landside & Airside \\
& $\mathbf{n}(\mathbf{\%})$ & $\mathbf{n}(\mathbf{\%})$ \\
\hline Sangat Tinggi & $11(10,48)$ & $1(3,13)$ \\
Tinggi & $32(30,48)$ & $10(31,25)$ \\
Sedang & $45(42,86)$ & $13(40,63)$ \\
Rendah & $12(11,43)$ & $6(18,75)$ \\
Sangat Rendah & $5(4,76)$ & $2(6,25)$ \\
\hline
\end{tabular}

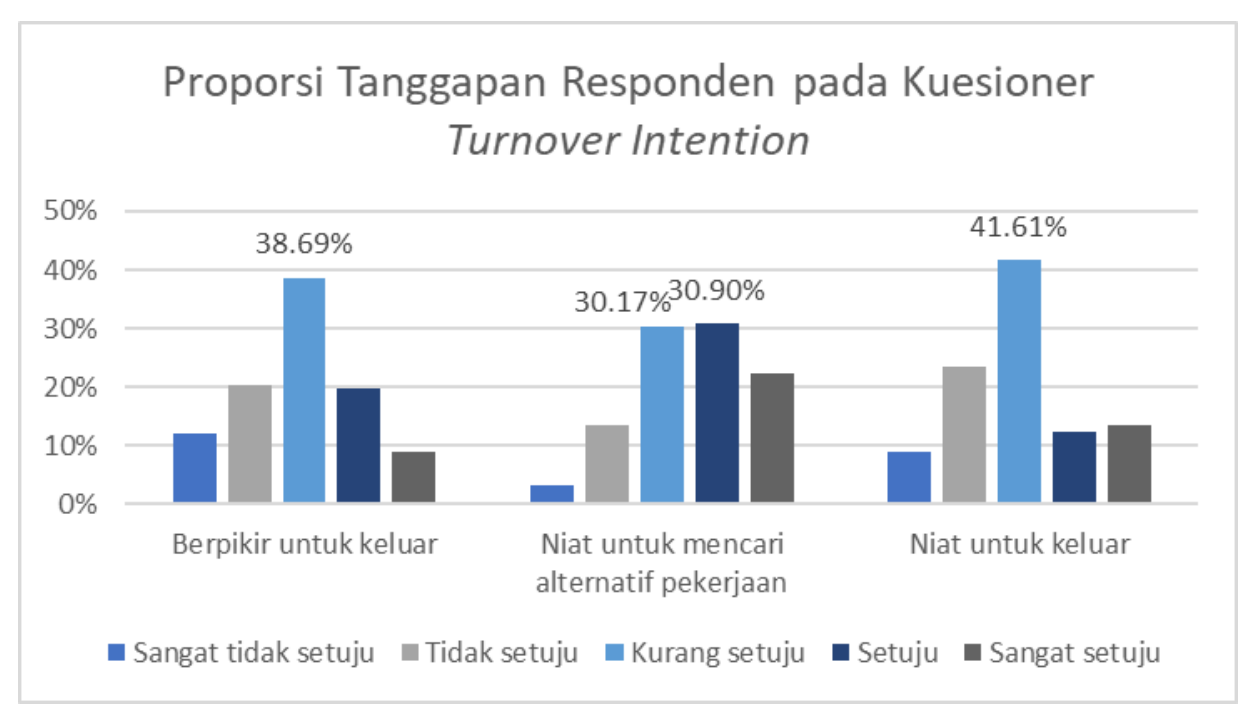

\section{Gambar 5. Proporsi Tanggapan Responden pada Kuesioner Turnover Intention}

Berdasarkan Gambar 5, pada indikator berpikir untuk keluar dan niat untuk keluar, responden dengan tanggapan kurang setuju merupakan yang terbanyak, yaitu $38,69 \%$ dan $41,61 \%$. Sedangkan, pada indikator niat untuk mencari alternatif pekerjaan tanggapan terbanyak adalah setuju, yaitu 30,9\%.

Pada Tabel 10, pada kelompok usia $\leq 25$ tahun, proporsi responden dengan turnover intention tinggi sama dengan proporsi turnover intention sedang, yaitu $39,58 \%$. Sedangkan, proporsi responden 
dengan turnover intention sedang merupakan yang terbesar pada kelompok usia $>25$ tahun (48,78\%). Pada variabel masa kerja, proporsi responden dengan turnover intention sedang merupakan yang terbanyak pada kedua kelompok. Pada kelompok masa kerja $\leq 3$ tahun sebesar $41,27 \%$ dan $43,24 \%$ pada kelompok masa kerja $>3$ tahun. Proporsi responden dengan turnover intention tinggi lebih besar pada kelompok masa kerja $>3$ tahun $(40,54 \%)$ daripada responden pada kelompok masa kerja $\leq 3$ tahun $(38,1 \%)$. Pada karakteristik tingkat pendidikan, proporsi turnover intention sedang merupakan yang terbanyak pada responden lulusan SMA/SMK $(44,74 \%)$ dan diploma $(44,68 \%)$. Sedangkan, proporsi turnover intention tinggi merupakan yang terbesar pada responden lulusan perguruan tinggi, yaitu $57,14 \%$

Tabel 10. Distribusi Turnover Intention Berdasarkan Karakteristik Responden

\begin{tabular}{lcccc}
\hline \multirow{2}{*}{$\begin{array}{c}\text { Karakteristik } \\
\text { Responden }\end{array}$} & $\begin{array}{c}\text { Tinggi } \\
\text { n (\%) }\end{array}$ & $\begin{array}{c}\text { Sedang } \\
\mathbf{n ~ ( \% )}\end{array}$ & $\begin{array}{c}\text { Rendah } \\
\mathbf{n ~ ( \% )}\end{array}$ & $\begin{array}{c}\text { Total } \\
\mathbf{n ~ ( \% )}\end{array}$ \\
\cline { 2 - 5 } & & & & \\
Usia & $38(39,58)$ & $38(39,58)$ & $20(20,83)$ & $96(100)$ \\
$\leq 25$ Tahun & $16(39,02)$ & $20(48,78)$ & $5(12,2)$ & $41(100)$ \\
$>$ 25 Tahun & & & & \\
Masa Kerja & $24(38,1)$ & $26(41,27)$ & $13(20,63)$ & $63(100)$ \\
$\leq 3$ Tahun & $30(40,54)$ & $32(43,24)$ & $12(16,22)$ & $74(100)$ \\
$>3$ Tahun & & & & \\
Pendidikan & $27(35,53)$ & $34(44,74)$ & $15(19,74)$ & $76(100)$ \\
SMA/SMK & $19(40,43)$ & $21(44,68)$ & $7(14,89)$ & $47(100)$ \\
Diploma & $8(57,14)$ & $3(21,43)$ & $3(21,43)$ & $14(100)$ \\
Perguruan Tinggi & $\mathbf{5 4}$ & $\mathbf{5 8}$ & $\mathbf{2 5}$ & $\mathbf{1 3 7}$ \\
\hline Total & & &
\end{tabular}

Tabel 11 menunjukkan proporsi turnover intention tinggi merupakan yang terbanyak pada responden dengan beban kerja fisik berat dan sedang, yaitu 54,55\% dan 41,1\%. Hasil uji korelasi spearman menunjukkan bahwa beban kerja fisik tidak memiliki hubungan dengan turnover intention. Hal ini dapat dilihat dari nilai $\mathrm{p}=0,2702$ yang lebih besar dari 0,05, sehingga Ho diterima.

Tabel 11. Hubungan Beban Kerja Fisik dengan Turnover Intention

\begin{tabular}{|c|c|c|c|c|c|c|}
\hline \multirow[b]{2}{*}{$\begin{array}{c}\text { Beban Kerja } \\
\text { Fisik }\end{array}$} & \multicolumn{3}{|c|}{ Turnover Intention } & \multirow[b]{2}{*}{$\begin{array}{l}\text { Total } \\
\text { n (\%) }\end{array}$} & \multirow[b]{2}{*}{$\mathbf{r s}_{\mathrm{s}}$} & \multirow[b]{2}{*}{$\mathbf{p}$} \\
\hline & $\begin{array}{l}\text { Tinggi } \\
\text { n (\%) }\end{array}$ & $\begin{array}{c}\text { Sedang } \\
\text { n (\%) }\end{array}$ & $\begin{array}{c}\text { Rendah } \\
\text { n (\%) }\end{array}$ & & & \\
\hline Berat & $6(54,55)$ & $4(36,36)$ & $1(9,09)$ & $11(100)$ & & \\
\hline Sedang & $30(41,1)$ & $29(39,73)$ & $14(19,18)$ & $73(100)$ & & \\
\hline Relatif Ringan & $18(33,96)$ & $25(47,17)$ & $10(18,87)$ & $53(100)$ & & \\
\hline \multirow[t]{2}{*}{ Total } & 54 & 58 & 25 & 137 & & \\
\hline & & & & & 0,0949 & 0,2702 \\
\hline
\end{tabular}


Berdasarkan Tabel 12, proporsi responden dengan turnover intention sedang merupakan yang terbesar pada kategori beban kerja mental tinggi dan sedang, yaitu $42,74 \%$ dan $42,11 \%$. Hasil uji korelasi spearman menunjukkan bahwa tidak terdapat hubungan antara beban kerja mental dengan turnover intention. Hal ini dapat dilihat dari nilai $\mathrm{p}=0,5181$ yang lebih besar dari 0,05, sehingga Ho diterima.

Tabel 12. Hubungan Beban Kerja Mental dengan Turnover Intention

\begin{tabular}{|c|c|c|c|c|c|c|}
\hline \multirow[b]{2}{*}{$\begin{array}{c}\text { Beban Kerja } \\
\text { Mental }\end{array}$} & \multicolumn{3}{|c|}{ Turnover Intention } & \multirow[b]{2}{*}{$\begin{array}{l}\text { Total } \\
\text { n (\%) }\end{array}$} & \multirow[b]{2}{*}{$\mathbf{r}_{\mathrm{s}}$} & \multirow[b]{2}{*}{$\mathbf{p}$} \\
\hline & $\begin{array}{l}\text { Tinggi } \\
\text { n (\%) }\end{array}$ & $\begin{array}{c}\text { Sedang } \\
\text { n (\%) }\end{array}$ & $\begin{array}{c}\text { Rendah } \\
\text { n (\%) }\end{array}$ & & & \\
\hline Tinggi & $47(40,17)$ & $50(42,74)$ & $20(17,09)$ & $117(100)$ & & \\
\hline Sedang & $6(31,58)$ & $8(42,11)$ & $5(26,32)$ & $19(100)$ & & \\
\hline Rendah & $1(100)$ & $0(0)$ & $0(0)$ & $1(100)$ & & \\
\hline Total & 54 & 58 & 25 & 137 & & \\
\hline & & & & & 0,0557 & 0,5181 \\
\hline
\end{tabular}

Tabel 13 menunjukkan bahwa

proporsi turnover intention tinggi paling besar pada kategori sangat lelah. Sedangkan pada kategori lelah dan tidak lelah, proporsi terbesar adalah responden dengan turnover intention sedang. Hasil uji korelasi spearman menunjukkan bahwa terdapat hubungan ringan positif antara kelelahan kerja dengan turnover intention. Hal ini dapat dilihat dari nilai $\mathrm{p}=0,0056$ yang lebih kecil dari 0,05, sehingga Ho ditolak. Nilai $r_{s}=0,2355$ yang berada pada rentang $0<\mathrm{r}_{\mathrm{s}}<0,4$ menunjukkan kekuatan hubungan

ringan.

Tabel 13. Hubungan Kelelahan Kerja dengan Turnover Intention

\begin{tabular}{|c|c|c|c|c|c|c|}
\hline \multirow[b]{2}{*}{$\begin{array}{c}\text { Kelelahan } \\
\text { Kerja }\end{array}$} & \multicolumn{3}{|c|}{ Turnover Intention } & \multirow{2}{*}{$\begin{array}{l}\text { Total } \\
\text { n (\%) }\end{array}$} & \multirow[b]{2}{*}{$\mathbf{r}_{\mathrm{s}}$} & \multirow[b]{2}{*}{$\mathbf{p}$} \\
\hline & $\begin{array}{l}\text { Tinggi } \\
\text { n (\%) }\end{array}$ & $\begin{array}{c}\text { Sedang } \\
\text { n (\%) }\end{array}$ & $\begin{array}{c}\text { Rendah } \\
\text { n (\%) }\end{array}$ & & & \\
\hline Sangat Lelah & $10(76,92)$ & $3(23,08)$ & $0(0)$ & $13(100)$ & & \\
\hline Lelah & $42(35,9)$ & $52(44,44)$ & $23(19,66)$ & $117(100)$ & & \\
\hline Tidak Lelah & $2(28,57)$ & $3(42,86)$ & $2(28,57)$ & $7(100)$ & & \\
\hline Total & 54 & 58 & 25 & 137 & & \\
\hline
\end{tabular}

\section{DISKUSI}

Gambaran karakteristik responden yang diukur pada penelitian ini adalah usia, masa kerja, dan pendidikan. Ditinjau berdasarkan karakteristik usia, rata-rata usia responden pada penelitian ini adalah 24 tahun dengan usia termuda 18 tahun dan usia tertua 42 tahun. Usia produktif seseorang menurut WHO (2014) berada pada rentang usia 15-64 tahun. Sama seperti yang dikemukakan oleh Badan Pusat Statistik Indonesia (2016) bahwa penduduk yang berusia 15 tahun atau lebih merupakan penduduk usia kerja. Sehingga, dapat disimpulkan bahwa seluruh pekerja 
outsourcing yang berpartisipasi sebagai responden pada penelitian ini berada pada kategori usia produktif.

Masa kerja merupakan jangka waktu atau lamanya seseorang bekerja pada suatu instansi (Koesindratmono \& Septarini, 2011). Masa kerja dihitung dari responden mulai pertama kali masuk kerja hingga dilakukannya penelitian. Rata-rata masa kerja responden pada penelitian ini adalah 4,26 tahun dengan masa kerja terlama responden adalah lima belas tahun dan tersingkat kurang dari satu tahun. Responden terikat kontrak dengan perusahaan penyedia tenaga outsourcing selama 1-3 tahun. Perpanjangan masa kontrak dilakukan dengan cara evaluasi kinerja pada tahun pertama dan ketiga. Maka dari itu, masa kerja pada penelitian ini dikelompokkan berdasarkan tahun evaluasi perpanjangan kontrak pekerja outsourcing, yaitu $\leq 3$ tahun sebagai masa kerja baru dan $>3$ tahun sebagai masa kerja lama.

Tingkat pendidikan menunjukkan pendidikan formal yang ditempuh oleh responden. Ditinjau dari tingkat pendidikan, sebagian besar responden merupakan lulusan SMA/SMK. Pendidikan merupakan salah satu syarat utama dalam penerimaan pekerjaan, dalam hal ini lulusan SMA/SMK merupakan jenjang pendidikan minimal untuk dapat diterima bekerja di PT X.

Distribusi beban kerja responden dikelompokkan menjadi beban kerja fisik dan beban kerja mental. Gambar 1 menunjukkan tanggapan responden pada kuesioner PLI untuk mengukur beban kerja fisik. Setiap bagian dalam kuesioner menggambarkan sikap kerja pada bagian tubuh tertentu. Hasil menunjukkan bahwa sikap kaki yang terdiri dari duduk, berdiri, jongkok, berlutut, dan berjalan paling sering dialami oleh sebagian besar responden. Dapat disimpulkan bahwa beban kerja responden secara fisik didominasi oleh sikap kaki pada saat bekerja.

Distribusi responden berdasarkan kategori beban kerja fisik yang disajikan pada Tabel 2 menunjukkan proporsi responden dengan beban kerja fisik kategori sedang merupakan yang terbanyak (53,28\%). Sedangkan, responden yang mengalami beban kerja fisik berat hanya sebanyak 8,03\%. Hasil berbeda ditemukan pada penelitian oleh Rahmawati et al (2016) pada porter PT Gapura Angkasa Cabang Bandara Ahmad Yani Semarang. Sebanyak 71,8\% responden menerima beban kerja fisik berat dan $28,2 \%$ dalam kategori beban kerja fisik sedang. Perbedaan tersebut dapat diakibatkan karena subjek pada penelitian tersebut hanya pada porter, bukan keseluruhan unit kerja sektor ground handling. Hasil pada penelitian ini menunjukkan rendahnya proporsi responden dengan beban kerja fisik berat. Hal ini dikarenakan pekerjaan para responden tidak banyak melibatkan aktivitas otot, serta kegiatan angkat-angkut sebagian besar dilakukan menggunakan bantuan mesin.

Pada Tabel 3 disajikan distribusi beban kerja fisik responden berdasarkan unit landside dan airside. Hasil menunjukkan bahwa distribusi beban kerja fisik responden pada unit landside serupa dengan distribusi beban kerja fisik responden secara keseluruhan. Namun, terdapat perbedaan antara distribusi beban 
kerja fisik pada unit airside dengan distribusi beban kerja fisik responden secara keseluruhan. Sebagian besar responden pada unit airside mengalami beban kerja fisik relatif ringan. Hal ini menunjukkan bahwa beban kerja fisik yang dirasakan oleh responden pada unit airside relatif lebih ringan daripada responden pada unit landside.

Selanjutnya pada Gambar 2 ditampilkan proporsi indikator beban kerja mental responden berdasarkan perbandingan berpasangan antar keenam indikator. Hasil menunjukkan bahwa tuntutan fisik lebih jarang dirasakan oleh para responden dalam melakukan pekerjaannya dibandingkan dengan indikator lainnya. Proporsi rating indikator beban kerja mental responden disajikan pada Gambar 3. Hal ini menunjukkan bahwa setiap indikator memberikan pengaruh sangat tinggi bagi sebagian besar responden.

Walaupun setiap indikator memiliki frekuensi yang berbeda-beda dirasakan oleh responden, namun masingmasing indikator memberikan pengaruh sangat tinggi bagi sebagian besar responden. Contohnya pada indikator physical demand (PD), yaitu tuntutan fisik jarang dirasakan oleh para responden dalam melakukan pekerjaannya. Namun, setiap tuntutan fisik yang dirasakan memberi pengaruh sangat tinggi bagi mayoritas responden dalam menyelesaikan pekerjaannya.

Tabel 4 menunjukkan distribusi proporsi beban kerja mental. Responden dengan beban kerja mental kategori sangat tinggi merupakan yang terbanyak, diikuti dengan responden dengan beban kerja mental tinggi. Sedangkan, responden dengan beban kerja mental rendah merupakan yang paling sedikit. Hasil serupa ditemukan pada penelitian oleh Poerwanto \& Gunawan (2015) pada pekerja bagian ground handling PT Gapura Angkasa Cabang Bandara Adisutjipto, yaitu ratarata beban kerja mental responden pada seluruh unit kerja berada pada kategori tinggi. Apabila ditinjau berdasarkan unit landside dan airside seperti yang tersaji pada Tabel 5, distribusi beban kerja mental responden pada setiap unit serupa dengan distribusi beban kerja mental responden secara keseluruhan. Hal ini menunjukkan bahwa beban kerja responden secara mental lebih tinggi dibandingkan dengan beban kerja secara fisik. Hasil sesuai dengan proses kerja di sektor ground handling yang lebih banyak melibatkan proses berpikir dari otak pekerja daripada menggunakan energi fisik otot.

Proporsi tanggapan responden pada kuesioner kelelahan kerja yang disajikan pada Gambar 4 menunjukkan bahwa responden cenderung mengalami pelemahan aktivitas dan merasakan gejala fisik saat lelah dibandingkan dengan mengalami pelemahan motivasi saat bekerja.

Distribusi proporsi kelelahan kerja responden pada Tabel 6 menunjukkan bahwa sebagian besar responden dalam keadaan lelah. Sedangkan, hanya sebagian kecil responden yang dinyatakan sangat lelah dan tidak lelah. Hasil serupa ditemukan pada penelitian oleh Makalalag et al (2017) pada tenaga kerja ground handling PT Gapura Angkasa Cabang Bandar Udara Internasional Sam Ratulangi Manado. Sebagian besar responden 
mengalami kelelahan sedang $(57,8 \%)$ dan hanya sebagian kecil responden mengalami lelah berat atau sangat lelah (13,3\%). Apabila ditinjau berdasarkan unit landside dan airside sesuai dengan yang tersaji pada Tabel 7, distribusi kelelahan kerja responden setiap unit serupa dengan distribusi kelelahan kerja responden secara keseluruhan. Maka dari itu dapat disimpulkan bahwa hampir seluruh responden pada penelitian ini mengalami kelelahan kerja.

Proporsi tanggapan responden seperti yang ditampilkan pada Gambar 5 menunjukkan tanggapan kurang setuju merupakan yang terbanyak pada indikator berpikir untuk keluar dan niat untuk keluar. Indikator berpikir untuk keluar menunjukkan pemikiran pekerja untuk keluar atau tetap berada di lingkungan pekerjaannya akibat rasa ketidakpuasan. Sedangkan, niat untuk keluar mencerminkan pekerja yang berniat untuk keluar dari tempat kerjanya. Pada indikator niat untuk mencari alternatif pekerjaan tanggapan terbanyak adalah setuju. Hal ini menunjukkan bahwa sebagian besar responden menunjukkan sikap setuju dalam hal niat untuk mencari alternatif pekerjaan.

Tanggapan kurang setuju oleh sebagian besar responden pada indikator berpikir untuk keluar dan niat untuk keluar menunjukkan sikap netral, yaitu antara setuju dan tidak setuju. Hasil tersebut bertolak belakang dengan riwayat turnover pekerja outsourcing pada tahun 2019 yang berada pada kategori tinggi. Perbedaan hasil penelitian dengan riwayat turnover perusahaan dapat diakibatkan oleh situasi pandemi Covid-19 saat penelitian berlangsung.

Pandemi Covid-19 berdampak pada hampir seluruh sektor kehidupan masyarakat. Kebijakan pemerintah dalam upaya mencegah penyebaran Covid-19 adalah dengan membatasi aktivitas masyarakat di luar rumah berpengaruh terhadap keberlangsungan hidup pekerja di Indonesia. Berdasarkan data Kementerian Ketenagakerjaan, setidaknya sebanyak 1.032 .960 pekerja di sektor formal dirumahkan dan sebanyak 375.165 pekerja di-PHK per 1 Mei 2020 (Gusman, 2020). Survei yang dilakukan oleh Lembaga Ilmu Pengetahuan Indonesia (LIPI) pada 1112 pekerja menunjukkan bahwa 15\% pekerja di-PHK tanpa pesangon dan hanya $2 \%$ pekerja yang di-PHK dengan pesangon. Dilihat dari segi pendapatan, 43\% masih memiliki pendapatan tetap. Namun, 20\% responden mengalami pengurangan pendapatan hingga $30 \%$ dan $10 \%$ responden pendapatannya berkurang sampai 50\%. Bahkan sebanyak 16\% pekerja tidak memiliki pendapatan (Ngadi, 2020).

Fenomena tersebut juga terjadi di PT X. Pekerja outsourcing ada yang dirumahkan atau bahkan mengalami putus kontrak, serta mengalami pengurangan pendapatan. Akibatnya, responden cenderung merasa bimbang dengan niat untuk pindah kerja. Selain itu, kesempatan untuk mendapatkan pekerjaan baru sangat kecil karena perusahaan lain juga mengalami nasib serupa. Responden lebih memilih untuk tetap berada di perusahaan tempat kerjanya saat ini daripada diputus kontrak kerjanya. Pekerja tentu lebih memprioritaskan adanya pemasukan 
untuk memenuhi kebutuhan sehariharinya.

Pada indikator niat untuk mencari alternatif pekerjaan, proporsi tanggapan setuju sedikit lebih besar daripada proporsi tanggapan kurang setuju. Niat untuk mencari pekerjaan mencerminkan perasaan pekerja yang ingin mencari pekerjaan lain dengan mulai sering berpikir untuk keluar dan mulai mencari alternatif pekerjaan yang dirasa lebih baik. Hal tersebut menunjukkan mayoritas responden pada saat penelitian masih memiliki niat untuk mencari pekerjaan yang lebih baik. Niat tersebut dapat diakibatkan oleh berkurangnya pendapatan pekerja karena pemotongan gaji, sehingga pekerja cenderung berharap untuk mendapatkan pekerjaan dengan pendapatan yang lebih tinggi.

Distribusi proporsi turnover intention responden yang ditunjukkan pada Tabel 8 menunjukkan bahwa sebagian besar responden berada pada kategori turnover intention sedang, diikuti dengan responden dengan turnover intention tinggi. Sedangkan, proporsi responden dengan turnover intention rendah dan sangat rendah berada pada posisi terendah. Distribusi turnover intention responden berdasarkan unit landside dan airside serupa dengan distribusi turnover intention responden secara keseluruhan. Besarnya proporsi responden dengan turnover intention sedang dapat disebabkan oleh situasi pandemi yang sedang berlangsung selama penelitian seperti yang telah diuraikan sebelumnya. Responden cenderung merasa bimbang dengan niat untuk pindah kerja, karena banyaknya sektor yang lumpuh selama pandemi. Data hasil penelitian bisa saja berbeda apabila pengambilan data dilakukan pada situasi normal.

Walaupun hasil secara keseluruhan menunjukkan bahwa setiap responden setidaknya memiliki keinginan untuk berpindah kerja, namun jumlah keseluruhan responden dengan turnover intention sedang, rendah, dan sangat rendah lebih besar daripada jumlah keseluruhan responden dengan turnover intention tinggi dan sangat tinggi. Hal ini menunjukkan bahwa mayoritas responden tidak memiliki keinginan pindah kerja tinggi.

Ditinjau dari karakteristik usia responden, seperti yang tersaji pada Tabel 10, proporsi responden dengan turnover intention tinggi pada kelompok usia $\leq 25$ tahun lebih tinggi daripada kelompok usia $>25$ tahun. Hasil sesuai dengan yang dikemukakan oleh Mobley (2011) bahwa pekerja muda memiliki tingkat turnover yang lebih tinggi daripada pekerja yang berusia lebih tua. Sehingga, semakin tua usia pekerja maka semakin rendah turnover intentionnya. Menurut Gilmer (1966), pekerja dengan usia muda masih memiliki keinginan untuk mencoba-coba pekerjaan serta ingin menumbuhkan keyakinan diri dari pengalamannya. Sedangkan, pekerja yang berusia lebih tua enggan untuk berpindah-pindah tempat kerja karena sudah memiliki tanggung jawab keluarga, mobilitas menurun, dan tidak ingin repot untuk memulai adaptasi dengan lingkungan kerja baru.

Selain itu, pada kelompok usia $>25$ tahun proporsi tertinggi adalah pada turnover intention sedang. Sedangkan, proporsi responden dengan turnover 
intention sedang dan turnover intention tinggi pada kelompok usia $\leq 25$ tahun adalah sama. Hal tersebut menunjukkan bahwa turnover intention sedang mendominasi kedua kelompok usia. Seperti yang telah dipaparkan sebelumnya, hal tersebut dapat disebabkan oleh pandemi Covid-19 yang berlangsung selama penelitian. Sehingga, responden cenderung merasa bimbang dengan niat untuk pindah kerja, karena kesempatan berkurang dan lebih memilih untuk menetap di tempat kerjanya saat ini.

Pada variabel masa kerja, proporsi turnover intention tinggi lebih banyak ditemukan pada responden yang telah bekerja selama $>3$ tahun. Hal ini berlawanan dengan yang diungkapkan oleh Mobley et al (1979), yaitu semakin lama masa kerja, maka semakin kecil kemungkinan seorang pekerja untuk berpindah dari pekerjaannya. Pada tahuntahun pertama bekerja, pekerja masih dalam tahap penyesuaian diri dalam lingkungan kerja dan belum terbiasa dalam menghadapi berbagai tantangan di tempat kerja. Selain itu, proporsi responden dengan turnover intention sedang merupakan yang terbanyak pada kedua kelompok masa kerja. Seperti yang telah dijabarkan sebelumnya, responden cenderung merasa bimbang dengan niat untuk pindah kerja dalam situasi pandemi.

Pada variabel pendidikan proporsi turnover intention tinggi merupakan yang terbesar pada responden lulusan perguruan tinggi, yaitu 57,14\%. Menurut Maier (1971), tingkat pendidikan memiliki pengaruh terhadap turnover. Tingkat pendidikan dengan jabatan yang sesuai dapat memengaruhi pekerja untuk menetap. Apabila pendidikan tidak sesuai dengan jabatan yang diinginkan, maka dapat meningkatkan intensi turnover pada pekerja.

Proporsi turnover intention sedang merupakan yang terbanyak pada responden lulusan SMA/SMK dan diploma. Selain itu proporsi responden lulusan perguruan tinggi lebih sedikit daripada lulusan SMA/SMK maupun diploma. Hasil tersebut juga menunjukkan bahwa responden cenderung merasa bimbang dengan niat untuk pindah kerja dalam situasi pandemi.

Berdasarkan hasil uji korelasi spearman pada Tabel 11 dan Tabel 12, ditemukan bahwa beban kerja fisik $(p=0,2702)$ dan beban kerja mental $(\mathrm{p}=0,5181)$ tidak memiliki hubungan dengan turnover intention. Hasil ini sejalan dengan penelitian yang dilakukan oleh Oktavianti (2017) yang menunjukkan bahwa tidak ada hubungan yang bermakna antara beban kerja $(p=0,113)$ dengan turnover intention. Namun, hasil berbeda ditemukan pada penelitian yang dilakukan oleh Putra \& Prihatsanti (2016) bahwa terdapat hubungan yang positif dan signifikan antara beban kerja $(\mathrm{p}=0,01)$ dengan turnover intention. Begitu pula dengan penelitian yang dilakukan oleh Siregar \& Winnarseh (2019), terdapat hubungan yang bermakna antara beban kerja $(p=0,01)$ dengan turnover intention. Hubungan tersebut menunjukkan bahwa semakin tinggi beban kerja, maka semakin tinggi pula turnover intention yang dimiliki pekerja.

Dalam penelitian ini didapatkan hasil bahwa responden cenderung mengalami beban kerja mental 
dibandingkan dengan beban kerja fisik. Walaupun hasil menunjukkan mayoritas beban kerja mental responden tinggi, namun tidak memiliki hubungan dengan turnover intention pekerja. Perbedaan hasil penelitian ini dengan penelitian lainnya dapat disebabkan oleh pengambilan data yang dilakukan pada situasi pandemi. Data beban kerja yang diperoleh bisa saja berbeda dengan data yang diambil pada situasi normal. Mengingat para pekerja juga mengalami penurunan intensitas kerja akibat penurunan aktivitas komersial di bandar udara.

Hasil uji korelasi spearman pada Tabel 13 menunjukkan bahwa terdapat hubungan ringan positif antara kelelahan kerja dengan turnover intention $(p=0,0056)$. Hasil serupa ditemukan juga pada penelitian yang dilakukan oleh Choi \& Kim (2013), yaitu terdapat hubungan ringan positif antara kelelahan dengan turnover intention $(\mathrm{p}=0,0089)$. Selain itu pada penelitian regresi oleh Rizal \& Badaruddin (2017) dan Ardiyanti (2019) ditemukan bahwa kelelahan kerja memiliki pengaruh yang signifikan terhadap turnover intention. Hal tersebut menunjukkan semakin lelah pekerja, maka kemungkinan pekerja mengalami turnover intention semakin tinggi.

Hasil penelitian ini diharapkan dapat dijadikan bahan pertimbangan atau masukan bagi pihak perusahaan dari aspek keselamatan dan kesehatan kerja. Pihak perusahaan diharapkan untuk lebih memerhatikan dampak beban kerja fisik dan mental serta kelelahan kerja terhadap para pekerjanya dalam jangka panjang. Hal ini dapat dituangkan dalam bentuk suatu program K3 yang berhubungan dengan pelayanan kesehatan bagi para pekerja. Pelayanan tersebut tidak hanya terbatas pada pemantauan kesehatan pekerja secara fisik, namun juga secara mental. Mengingat berdasarkan hasil penelitian ini, beban kerja mental lebih dominan dirasakan oleh para responden dibandingkan dengan beban kerja fisik. Promosi kesehatan mental sebagai upaya preventif dan skrining kesehatan mental dapat diberikan secara berkala kepada para pekerja. Dengan diterapkannya suatu program pemantauan kesehatan pekerja yang komprehensif, maka kesehatan para pekerja dapat terpantau dengan baik. Sehingga, dapat disusun rencana penanggulangan yang tepat sasaran. Diharapkan pula dapat berdampak pada pengurangan angka turnover pekerja di perusahaan dalam jangka panjang. Program yang fokus kepada kesejahteraan tenaga kerja dapat membuat pekerja lebih betah untuk tetap berada di perusahaannya.

\section{SIMPULAN}

\section{Berdasarkan}

karakteristik responden, sebagian besar responden berusia $\leq 25$ tahun, sebagian besar telah bekerja selama lebih dari 3 tahun, dan sebagian besar merupakan lulusan SMA/SMK. Proporsi responden dengan beban kerja fisik kategori sedang merupakan yang terbanyak. Sedangkan, responden dengan beban kerja mental kategori sangat tinggi merupakan yang terbanyak. Sebagian besar responden pada variabel kelelahan kerja berada dalam kategori lelah. Sebagian besar responden memiliki turnover intention kategori sedang. Beban kerja fisik $(p=0,2702)$ dan beban kerja 
mental $\quad(p=0,5181) \quad$ tidak memiliki hubungan dengan turnover intention. Kelelahan kerja memiliki hubungan ringan positif dengan turnover intention $(\mathrm{p}=0,0056)$.

\section{SARAN}

Berdasarkan hasil penelitian, saran yang dapat diberikan yaitu, bagi peneliti selanjutnya diharapkan untuk menggunakan instrumen yang objektif pada pengukuran beban kerja dan kelelahan kerja. Contohnya pada beban kerja fisik dengan mengukur denyut nadi kerja dan istirahat. Sedangkan pada kelelahan kerja menggunakan reaction timer, sehingga data yang dihasilkan lebih objektif. Diharapkan pula untuk mempertimbangkan situasi di lapangan sebelum melakukan penelitian serta mempertimbangkan variabel-variabel pendukung lainnya terkait turnover intention, seperti lingkungan kerja, kepuasan kerja, dan komitmen organisasi untuk mendapatkan hasil yang lebih objektif.

Bagi responden diharapkan untuk tetap mempertahankan integritas kerja dan tanggung jawab dalam bekerja tanpa merasa terbebani oleh rasa lelah. Serta diharapkan untuk lebih memahami dampak turnover dalam jangka panjang baik bagi individu maupun bagi perusahaan, sehingga dapat mengambil keputusan yang tepat.

Bagi manajemen perusahaan diharapkan untuk lebih memerhatikan jumlah pekerja supaya distribusi tugas merata. Sehingga, pekerja tidak menanggung beban kerja berlebih dan tingkat kelelahan kerja dapat dikurangi. Diharapkan untuk melakukan pemeliharaan pekerja dengan meningkatkan pelayanan penunjang kesejahteraan tenaga kerja, serta pemberian reward dalam upaya mempertahankan para pekerja outsourcing.

\section{DAFTAR PUSTAKA}

Ardiyanti, I. (2019). Pengaruh Kelelahan Kerja dan Kepuasan Kerja Terhadap Turnover Intention. Jurnal Inspirasi Bisnis dan Manajemen, 3 (1): 11-20.

Badan Pusat Statistik Indonesia. (2016). Konsep dan Penjelasan Teknis. Jakarta: Badan Pusat Statistik Indonesia.

Budiono, S.A.M. (2008). Bunga Rampai Higiene Perusahaan Ergonomi (HIPERKES) dan Kesehatan dan Keselamatan Kerja. Semarang: Badan Penerbit Universitas Diponegoro.

Choi, S.E. \& Kim, S.D. (2013). Relationships of Fatigue to Job Satisfaction and Turnover Intention among Clinical Nurses at Small \& Medium-Sized Hospitals. Journal of the Korea Academia-Industrial cooperation Society, 14 (9): 4218-4226.

Departemen Kesehatan RI. (2009). Profil Kesehatan Indonesia. Jakarta: Depertemen Republik Indonesia.

Dwiningtyas. (2015). “Pengaruh Kepuasan kerja, Stress kerja dan Lingkungan kerja terhadap Turnover intention pada Karyawan CV. Aneka Ilmu Semarang". Skripsi. Jurusan Manajemen Fakultas Ekonomi Universitas Semarang. Semarang.

Ghosh, P. et al. (2013). Who stays with you? Factors predicting employees' intention to stay. International Journal of Organizational Analysis Bingley, 21 (3): 288-312. 
Gilmer, V.H. (1966). Industrial psychology. USA: McGraw Hill Book Company Inc.

Girdano, D. \& Everly, G. (1980). Controlling stress and tension: A holistic approach. Upper Saddle River: Prentice Hall.

Gusman, H. (2020, Mei 29), “Ketika Pandemi COVID-19 Berdampak pada Nasib Jutaan Pekerja RI", (Tirto.id), Available: https:/tirto.id/fDai (Accessed: 2020, Juni 12).

Hart, S.G \& Staveland, L.E. (1988). Development of NASA-TLX (Task Load Index) result of empirical and theoretical research. Amsterdam: North-Holland.

Hollmann, S. et al. (1999). Validation of a questionnaire for assessing physical work load. Scandinavian Journal of Work, Environment \& Health, 25 (2): 105-114.

Irvianti, L.S.D \& Verina, R.E. (2015). Analisis Pengaruh Stres Kerja, Beban Kerja dan Lingkungan Kerja Terhadap Turnover intention Karyawan pada PT XL Axiata Tbk Jakarta. Binus Businness Review, 6 (1): 117-126.

Koesindratmono, F. \& Septarini, B.G. (2011). Hubungan antara Masa Kerja dengan Pemberdayaan Psikologis pada Karyawan PT. Perkebunan Nusantara X (Persero). INSAN Media Psikologi,13 (01): 5057.

Maier, N.R.F. (1971). Psychology in Industry $3^{\text {rd }}$ edition. Cambridge: The Riverside Press.

Makalalag, R.N.A., Kalesaran, A.F.C., \& Kawatu, P.A.T. (2017). Hubungan
Antara Intensitas Kebisingan

Dengan Kelelahan Kerja pada Tenaga Kerja Ground Handling PT. Gapura Angkasa Bandar Udara Internasional Sam Ratulangi Kota Manado. Media Kesehatan, 9 (3).

Manuaba. (2000). Hubungan Beban Kerja dan Kapasitas Kerja. Jakarta: Rinek Cipta. Mobley, W.H, Hollingsworth, A.T \& Horner, S.A. (1978). An evaluation of precursors of hospital employee turnover. Journal of Applied Psychology, 63 (4): 408-414.

Mobley, W.H. (2011). Pergantian Karyawan: Sebab, Akibat dan Pengendaliannya. Alih Bahasa: Nurul Imam. Jakarta: PT Pustaka Binaman Pressindo.

Mobley, W.H. et al. (1979). Review and conceptual analysis of the employee turnover process. Psychological Bulletin, 86: 493-522.

Mora, M. (2012). Telaahan Literatur Tentang Program Perawatan Pesawat Udara. Jurnal Penelitian Perhubungan Udara Warta Ardhia, 38 (4).

Ngadi. (2020, Mei 4), “Hasil Survei Dampak Pandemi Covid-19 pada Pekerja", (Lembaga Ilmu Pengetahuan Indonesia), Available: http://lipi.go.id/siaranpress/hasilsurvei-dampak-pandemi-covid-19pada-pekerja/22011 (Accessed: 2020, Juni 12).

Oktavianti, W. (2017). "Hubungan Beban Kerja dengan Turnover Intention di Ruang Rawat Inap Rumah Sakit Umum Daerah Sidoarjo". Skripsi. Fakultas Keperawatan Universitas Airlangga. 
Poerwanto, E \& Gunawan. (2015). Analisis

Beban Kerja Mental Pekerja Bagian Ground Handling Bandara Adisutjipto untuk Mendukung Keselamatan Penerbangan. Jurnal Angkasa, 7 (2): 115-126.

Putra, M.T.P. \& Prihatsanti, U. (2016). Hubungan Antara Beban Kerja dengan Intensi Turnover pada Karyawan di PT. " $X^{\prime}$. Jurnal Empati, 5 (2): 303-307.

Rahmawati F., Suroto, Wahyuni, I. (2016). Hubungan Antara Beban Kerja Fisik dengan Tingkat Kebugaran Jasmani Pekerja Bagian Ground Handling di Bandara Ahmad Yani Semarang (Studi Kasus pada Pekerja Porter PT. Gapura Angkasa). Jurnal Kesehatan Masyarakat (e-Journal), 4 (3): 383-393.

Rizal, S. \& Badaruddin. (2017). Pengaruh kelelahan kerja dan iklim organisasi terhadap keinginan karyawan untuk berpindah pada PT. Oto Finance Cabang Banda Aceh. Jurnal Ekonomi Manajemen dan Akutansi, 3 (1): 32-43.
Roseman, E. (1981). Managing Employee Turnover: A Positive Approach. New York: AMACOM.

Setyawati, L.M. (2010). Selintas Tentang Kelelahan Kerja. Yogyakarta: Amara Books.

Siregar, T. \& Winnarseh, W. (2019). Korelasi Beban Kerja Dengan Potensial Turnover Perawat Di Rumah Sakit Ali Sibroh Malisi Jakarta Selatan. Jurnal Persada Husada Indonesia, 6 (21): 43-52.

Suma'mur, P.K. (2009). Higiene Perusahaan dan Kesehatan Kerja. Jakarta: CV. Sagung Seto.

Suwanto, Ariani, N. \& Novikasari, L. (2014). Hubungan Beban Kerja dengan Minat Pindah Kerja pada Perawat Tenaga Kerja Sukarela (TKS) di Rumah Sakit Tk IV 02.07.04 Bandar Lampung Tahun 2013. Jurnal Kesehatan Holistik, 8 (3): 131-137.

World Health Organization. (2014). The Health of the People: What Works. Ganeva: World Health Organization. 